\title{
THE QUIET OF DISSOLUTION: POST-DisASTER REDEVELOPMENT AND STATUS-PRESERVING COMPENSATION
}

\author{
David V. Simunovich*
}

To add to the gloom, almost every living thing seems to have departed, and not a whistle of a bird nor the bark of the squirrel can be heard in this solitude. Sometimes a morose gar will throw his tail aloft and disappear in the river, but beyond this everything is quiet - the quiet of dissolution. Down the river floats now a neatly whitewashed hen-house, then a cluster of neatly split fence-rails, or a door and a bloated carcass, solemnly guarded by a pair of buzzards, the only bird to be seen, which feast on the carcass as it bears them along. A picture-frame in which there was a cheap lithograph of a soldier on horseback, as it floated on told of some hearth invaded by the water and despoiled of this ornament. ${ }^{1}$

Mark Twain, 1882

\section{INTRODUCTION}

Though written more than a century ago, Twain's account of the devastation wrought by that unnamed storm conveys a scene of utter ruin and hopelessness-a scene repeated all too frequently in the wake of major disasters. More recently, Hurricane Katrina, the costliest $^{2}$ and third deadliest ${ }^{3}$ hurricane in American history, caused a

* J.D., anticipated May 2008, Seton Hall University School of Law; 2005, M.S.T., Pace University Graduate School of Education; 2002, B.A., summa cum laude, Political Science, University of California, Los Angeles. Many thanks to my parents, my brother, and Ami Doshi, for their continued love and support. Additionally, I owe a debt of gratitude to Professors Rachel Godsil and Shavar Jeffries for their guidance and advice throughout my legal education.

${ }^{1}$ Mark Twain, Voyage of the Times-Democrat's Relief Boat Through the Inundated, NEW ORLEANS Times DEMOCRAT, Mar. 29, 1882, available at http://whitewolf.newcastle.edu $. \mathrm{au} /$ words/authors/T/TwainMark/prose/lifeonmississippi/appendixa.html.

${ }^{2}$ Fed. Emergency Mgmt. Agency, High Water Mark Collection for Hurricane KATRINA IN ALABAMA 6 (2006).

3 Fed. Emergency Mgmt. Agency, Summary Report on Building Performance: HURricANE KATRINA 2005, at 1-5 (2006) [hereinafter FEMA, BuILDING PERFORMANCE]. 
sense of stillness and quietude reminiscent of Twain's description of the storm-ravaged Gulf Coast. However, despite Katrina's devastation, disaster recovery itself need not be wholly disruptive to Gulf Coast communities. ${ }^{4}$ Post-disaster redevelopment provides residents, policy makers, and community agents with the potential to "implement technologies and practices which afford a stronger and more sustainable future." ${ }^{5}$ This Comment explains one method of facilitating the transition from the quiet of dissolution to the boom of effective, efficient, and equitable redevelopment. ${ }^{6}$

Hurricane Katrina was "gargantuan in size," measuring 460 miles in diameter ${ }^{7}$ and registering wind speeds up to 175 miles per hour. ${ }^{8}$ The intensity of the storm surge forced the Mississippi River to temporarily flow backwards, ${ }^{9}$ flooded 148 square miles of urban landscape ${ }^{10}$ and elevated the water level in one lake more than eleven feet in nine hours. ${ }^{11}$ Katrina spread more than twenty-four million tons of debris over the Louisiana landscape, submerged 350,000 automobiles, and damaged more than 60,000 vessels. $^{12}$ To date, more than fifty-nine billion federal dollars have been committed to post-Katrina redevelopment. ${ }^{13}$ Most troubling, the storm took the lives of approximately 1500 individuals. ${ }^{14}$

\footnotetext{
${ }^{4}$ Operation Fresh Start Recovery Assistance Programs, http://www.freshstart .ncat.org/assist.htm (last visited Oct. 15, 2007).

Id.

${ }^{6}$ While this Comment focuses on Hurricane Katrina's effect on the Gulf Coast, the material facts and statutory framework is relevant to any post-disaster redevelopment process.

7 Douglas Brinkley, The Great Deluge: Hurricane Katrina, New Orleans, AND THE MisSISSIPPI GULF COAST 132 (2006).

${ }^{8}$ Id. at 221.

${ }^{9} I d$. at xiii.

${ }^{10}$ Ivor Van Heerden \& Mike Bryan, The Storm: What Went Wrong and Why During Hurricane Katrina-The Inside Story From One Louisiana Scientist 109 (2006).

11 Elizabeth Kolbert, Watermark: Can Southern Louisiana Be Saved?, NEw Yorker, Feb. 27, 2006, at 54.

12 Louisiana Recovery Authority, 2006 Quarterly RePOrt: JunE-August 11 (2006), available at http://www.lra.louisiana.gov/assets/quarterlyreport/LRAQuar terlyReportAugust2006_update.pdf [hereinafter LRA, JUNE-AUG. QUARTERLY REPORT].

${ }^{13} I d$. at 12

${ }^{14}$ Charles C. Mann, The Long, Strange Resurrection of New Orleans, FortunE, Aug. 21,2006 , at 86 . The precise number of hurricane-related deaths is not entirely clear. See, e.g., LRA, JUNE-AUg. QUARTERLY RePORT 2 (referring to Hurricanes Katrina and Rita as "taking nearly 1,500 lives"); FEMA, BuILDING PERFORMANCE, supra note 3, at 15 (citing death toll of approximately 1,300$)$.
} 
One of the neighborhoods most devastated by Katrina was the Lower Ninth Ward. ${ }^{15}$ This neighborhood of 14,000 residents ${ }^{16}$ sits, in some places, four feet below sea level and was flooded by eighteen feet of water when the levees failed. ${ }^{17}$ The levee breach produced "truly catastrophic results," 18 and sent forth a wall of water that demolished homes in its immediate vicinity, caused extensive flooding in others, and ultimately took the lives of hundreds in less than two hours. ${ }^{19}$

While approximately ninety-eight percent of Lower Ninth residents were African American, ${ }^{20}$ Katrina's destructive capacity did not discriminate. "In the [Orleans, Jefferson, and St. Bernard Parishes], people of color represented $52 \%$ of the pre-Katrina population and $53 \%$ of the dead .... [T] he storm flooded $51 \%$ of the whiteoccupied homes and $67 \%$ of the black-occupied homes in the threeparish area ...." While the storm destroyed without regard to race and wealth, the burden of redevelopment will fall particularly hard on the poor, which include most Lower Ninth residents. ${ }^{22}$

The lasting effects of Katrina are fundamentally different than the more transient consequences that follow minor flooding or wind damage. Researchers analogized Katrina's effects to the nuclear disaster at Chernobyl ${ }^{23}$ and called for "pioneering thinking" in restoring the Gulf Coast. ${ }^{24}$ Without such pioneering thinking-or, at a minimum, strong and sustained leadership—redevelopment is bound to stumble along in an inefficient and inequitable manner. For example, in the absence of a program that encouraged efficient redevelopment, the city was plagued by "jack-o-lantern neighborhoods," where "residents are scattered among abandoned houses" throughout the city limits. ${ }^{25}$ This population pattern creates a severe strain on public services and infrastructure at a time when city services, as a

${ }^{15}$ See Dan Baum, The Lost Year: Behind the Failure to Rebuild, New Yorker, Aug. 21, 2006 , at 46.

${ }^{16} I d$.

17 VAN HeERden \& BRyan, supra note 10, at 84.

${ }_{18} I d$.

19 I.

${ }^{20}$ Baum, supra note 15 , at 46.

21 Mann, supra note 14, at 96.

22 See id.; see also infra notes 181-87 and accompanying text.

James P. Kahan et al., From Flood Control to InTEgrated Water Resource Management: Lessons For the Gulf CoAst From FloOding in Other Places in the LAST SIXTYYEARS 39 (2006).

${ }^{24} I d$.

${ }^{25}$ Mann, supra note 14, at 96. 
result of high rates of unemployment and severely reduced population, can least afford such demands. ${ }^{26}$

In response to the devastation, local, ${ }^{27}$ state,$^{28}$ and federal ${ }^{29}$ officials attempted to deliver some sense of normalcy to the hurricane's victims by proposing or implementing various policies. One product of these efforts is the Road Home, a program designed and implemented by state lawmakers, but funded and approved by the U.S. Department of Housing and Urban Development. ${ }^{30}$ The Road Home provides qualified Louisiana residents with grants of up to $\$ 150,000$ for uncompensated storm-related damage to their homes. ${ }^{31}$ The plan provides grants for home renovation and also permits qualified homeowners to sell property to the state at a pre-disaster fair market value. $^{32}$ Homeowners also retain the right to sell property privately on the open market. ${ }^{33}$ This federally funded program "represents the largest single housing recovery program in U.S. history." 34

${ }^{26}$ Michele Krupa, Recovery Reports to Hasten Federal Cash Flow, Times-PiCAYunE (New Orleans), Oct. 21, 2006, at 1. Krupa notes that Congress allocated more than $\$ 10$ billion to the state of Louisiana in recovery aid, yet the bulk of that money is earmarked for the state's housing crisis. Id. This leaves approximately $\$ 645$ million dollars for parishes to redevelop critical infrastructure, $\$ 200$ million of which was awarded to assist Entergy, a major employer and provider of public utilities, leaving $\$ 445$ million to be divided among eleven storm-damaged parishes. Id.

This lack of funding for critical infrastructure development will likely place greater pressure on city planners to reduce the city's footprint, i.e., concentrate redevelopment in limited areas, thereby maximizing the impact of reduced infrastructure redevelopment. This, in turn, may place greater pressure on the city to implement the buyout-only provision of the Road Home program. The criteria for this funding restriction are left unarticulated. A major concern is that this funding shortage will increase the pressure on Road Home administrators to cast a wider net on the areas in which homeowners will not have the opportunity to benefit from Road Home renovation funding.

27 See, e.g., Gary Rivlin, Storm and Crisis: Rebuilding, N.Y. TIMEs, Oct. 1, 2005, at A11 (describing commission created by New Orleans Mayor Ray Nagin).

${ }^{28}$ See, e.g., Katrina Recovery Panel Announced, WASH. POST, Oct. 18, 2005, at A11 (describing creation of the Louisiana Recovery Authority by Governor Kathleen Babineaux Blanco).

29 See, e.g., Adam Nossiter, \$29 Billion Package Buoys Hopes for Rebuilding Effort, N.Y. Times, Dec. 24, 2005, at A11 (describing Congressman Richard Baker's proposed multi-billion-dollar recovery program).

30 LOUISIANA RECOVERY AUTHORITY, 2006 QUARTERLY REPORT: FEBRUARY-MAY 1314 (2006), available at http://lra.louisiana.gov/assets/quarterlyreport/LRAQuarterly Report060606pdf.pdf [hereinafter LRA, FEB.-MAY QUARTERLY REPORT].

Id.

32 LOUisiana Recovery Authority, The RoAd Home Overview 8 (2006), available at http://www.lra.louisiana.gov/assets/RoadHomecomplete053006.pdf [hereinafter LRA, ROAD HOME OVERVIEW].

33 Id.

${ }^{34}$ LRA, JUNE-AUg. QUARTERLy RePORT, supra note 12, at 9. 
The Road Home offers maximum financial assistance to homeowners who choose to rebuild or relocate within Louisiana. ${ }^{35}$ If homeowners resided in a Federal Emergency Management Agency (FEMA)-designated floodplain before the storm made landfall but did not carry insurance, ${ }^{36}$ or if they elect to move outside of the state rather than rebuild in their communities, ${ }^{37}$ they may receive Road Home assistance, but not the full $\$ 150,000$ grant. $^{38}$

The basic contours of the Road Home are largely commendable. It provides much-needed support to protect the homeowner status of Katrina-displacees and at the same time provides program administrators the flexibility to concentrate redevelopment in order to maximize the impact of a scarce resource-federal financial support. Yet the program remains fundamentally flawed. It unnecessarily creates a cloud of confusion around the benefits and restrictions relevant to Louisiana's most vulnerable homeowners.

A critical provision buried within the administrative innards of the Road Home holds that residents living in areas "where a high proportion of homeowners are choosing not to invest" in their homes may not be eligible for the $\$ 150,000$ rehabilitation grants. ${ }^{39}$ Rather, such homeowners may sell their homes to the state at a pre-flood fair market value, sell on the open market, or finance the renovations themselves. $^{40}$ Compounding the problem, program administrators never articulated the standards to be used in identifying which neighborhoods, if any, would be subject to the funding restriction. ${ }^{41}$

35 LRA, ROAD HOME OVERviEW, supra note 32, at 6.

${ }^{36} I d$. at 12 . "[A] $30 \%$ penalty applies to those who failed to purchase insurance for their homes. A penalty applies to those without flood insurance in a designated flood plain and those without hazard insurance that were outside the flood plain." Id.

Id. at 9. If a homeowner chooses to sell her home to the state, the homeowner will receive sixty percent of the property's pre-storm fair market value. $I d$.

${ }^{38} I d$. at $9,12$.

39 Louisiana Recovery Authority, The RoAd Home Housing Programs Action Plan AMENDMENT FOR DisASTER RECOVERY FUnDS 6-7 (2006), available at http://www.lra.louisiana.gov/assets/roadhome/HousingActionPlanAmendment050 306.pdf [hereinafter LRA, ACTION PLAN AMENDMENT].

Id. at 7.

${ }^{41} I d$. To date, program administrators have not expressly implemented the provision. However, regardless of whether the buyout restriction is ultimately implemented, the provision's pernicious effects were felt in the months immediately following the storm, when residents made relocation decisions. Without clearly articulated standards, the ambiguity of who would receive benefits-aside from how much a resident would receive-would have invariably deterred residents who lacked the financial ability to self-finance a major home renovation (precisely the homeowners who would benefit most from government assistance). See infra Part III.C.2. 
The Road Home's buyout-only restriction is, in the abstract, a reasonable and legitimate provision in light of the fact that the population of New Orleans dwindled to 190,000 one year after the storm, ${ }^{42}$ less than half of its pre-storm population of $455,000 .^{43}$ Notwithstanding the reasonableness of the provision in the abstract, the practical effect of the restriction works an inequitable harm on displaced residents targeted by the program's efforts to constrict the city's size, or its "footprint." While the initial and perhaps most critical postKatrina redevelopment planning has passed, this issue must be confronted as natural disasters will inevitably affect communities across America, ${ }^{44}$ and redevelopment plans will invariably follow. Plans similar to the Road Home may be common in the future, as it combines flexibility and discretion at the administrative level with a concern for the homeowner status of displacees at the beneficiary level. ${ }^{45}$

This Comment asserts that Katrina-displaced homeowners are eligible for benefits beyond the buyout-only provisions of the Road Home under the Uniform Relocation Assistance and Real Property Acquisition Policies for Federal and Federally Assisted Programs (URA). ${ }^{46}$ As noted above, the buyout-only provision limits a homeowner's options to self-financed renovation, open market sale, or a state buyout at a pre-storm fair market value. ${ }^{47}$ The first two options

${ }^{42}$ James Varney, Resident Count Comes in Low, Times-PiCAYune (New Orleans), Oct. 6,2006 , at 1 .

43 Mann, supra note 14, at 94.

44 See, e.g., Intergovernmental Panel on Climate Change, Climate Change 2007: The Physical SCIENCE BASIS 12 (2007). The Intergovernmental Panel on Climate Change (IPCC) issued a report on February 3, 2007, described as "a collaboration of hundreds of scientists and government officials, [that] was approved by 113 nations, including the United States." Angela Charlton \& Seth Borenstein, $46 \mathrm{Na}$ tions Back Body to Protect Planet, Associated Press, Feb. 4, 2007, available at http:// www.breitbart.com/news/2007/02/04/D8N2QEGG0.html. The IPCC noted both a trend toward stronger storm systems in the last three decades, and a likelihood that future storm systems will grow less frequent but more severe. INTERGOVERNMENTAL Panel on Climate Change, supra, at 6-12.

${ }^{45}$ It should also be noted that the Uniform Relocation Assistance and Real Property Acquisition Policies for Federal and Federally Assisted Programs (URA) is best equipped to avoid repetitive losses, "[o]ne of the most serious consequences of the National Flood Insurance Program." Rutherford H. Platt, Disaster AND Democracy: The Politics of Extreme Natural Events 31 (1999). As of 1999, two percent of insured properties consumed "over one-quarter of all [National Flood Insurance Program] claims . . . [and forty] percent of all [National Flood Insurance Program] payments." Id. at 31-32. Compensation under the URA largely avoids this problem as it permits government officials to reduce exposure to repetitive losses, while providing homeowners with a guarantee of comparable replacement housing. See infra Part II.

4642 U.S.C. $\$ \S 4601-4655$ (2000).

${ }^{47}$ See supra notes 39-40 and accompanying text. 
do not present affected low-income homeowners with reasonable alternatives. The third option is the only realistic choice that affected low-income homeowners will have if program administrators, using whatever metric they ultimately decide upon, designate an area as buyout only. Moreover, homeowners who relocated in the wake of the storm because of the ambiguity surrounding Road Home benefits and reestablished families, employment, and affordable housing in other areas around the country will face the same pressure to sell property to the state under the buyback provision. Though the buyback provision does not amount to a Fifth Amendment taking, the involuntariness of the transaction nevertheless triggers URA displacement benefits.

Part I of this Comment discusses Katrina's impact on New Orleans generally, and the Ninth Ward particularly, as well as factors indicating that natural disasters will continue to plague the Gulf Coast. Part II explains the statutory protections extended to displaced persons under the URA. Part III explores three theories that advocates can utilize to ensure the application of status-preserving compensation under the URA to homeowners displaced by the Road Home.

\section{GULF COAST SUSCEPTIBILITY TO NATURAL DISASTERS}

Much has been made of the sheer strength and size of Katrina. However, by the time it made landfall in Louisiana, it was a relatively pedestrian meteorological event. ${ }^{48}$ The more profound and lasting issue is the Gulf Coast's vulnerability to even medium-sized hurricanes, caused by a confluence of disappearing wetlands, subsiding land, and an inadequate levee system. This convergence of factors led some scientists to characterize the Louisiana coastal region as "the very definition of an inherently vulnerable landscape."

The Louisiana coastline is distinguished by its vast network of swamps and marshes, which account for a large portion of America's

48 VAN HEERDEN \& BRYAN, supra note 10, at 85 (noting that Hurricane Katrina's winds were reduced to ninety-eight miles per hour-a Category Two storm-on landfall). Van Heerden and Bryan note that,

[a]s Katrina should have affected New Orleans proper, she was decidedly a medium hurricane. Sometime in the foreseeable future a bigger storm will not take that last-minute jog to the east and every square foot of New Orleans-all of it, not just 80 percent [as was the case with Katrina] — will be underwater, and deeper underwater than this time. Id. at 10 .

${ }^{49} I d$. at 4 . 
wetlands. ${ }^{50}$ In the past, the wetlands provided a crucial buffer between Louisiana coastal communities and Gulf storm systems. ${ }^{51}$ However, in the last several decades, these protective wetlands disappeared at an alarming rate. ${ }^{52}$

In addition to the disappearing wetlands, a recent study indicates that New Orleans and its levees are sinking into the Mississippi River, with a period of drastic subsidence between the years 2002 and 2005. ${ }^{53}$ Currently, most of New Orleans is about five feet below sea level, ${ }^{54}$ and the city is subsiding at a rate of one inch per year. ${ }^{55}$ This rate of subsidence may seem trivial, but some levees are now three feet lower than originally planned, substantially reducing the protection they were intended to provide. ${ }^{56}$ Explaining the protections ostensibly provided by the levees, one oil company executive noted that

"[i]n the offshore [oil] business ..., we design major structures in the Gulf for a 100-year wave height. Because that height is an estimate, engineers add a safety factor of four to six for manned structures-that is, they build the structure to withstand a wave that is four to six times as high as the theoretical maximum." . . By contrast, ... the safety factor of New Orleans is 1.3. Surprised by this low standard, [researchers] traced it back to the 1940's when the [Army Corps of Engineers] used a 1.3 safety factor to protect agricultural land-cows in other words-against flooding. ${ }^{57}$

While a safety factor of 1.3 may seem woefully inadequate to protect human life, when the levees were originally designed and con-

50 Id. at 153 .

51 Mann, supra note 14, at 109; see also David Owens, Land Acquisition and Coastal Resource Management: A Pragmatic Perspective, 24 WM. \& MARY L. REV. 625, 625-26 (1983) (providing a concise review of the benefits of viable wetlands).

${ }^{52}$ BRINKLEY, supra note 7 , at 9 . One journalist recounted the variety of comparative measurements used to convey the rate at which land is being lost on the Louisiana coastline: "The region ... is losing land at the rate of a football field every thirty eight minutes. Alternatively, it is said, the area is shrinking by a large desktop's worth of ground every second, or a tennis court's worth every thirteen seconds, or twenty-five square miles a year." Kolbert, supra note 11, at 48 . One estimate indicates that an additional seven hundred square miles of coastal marshland will be lost by 2050." BRINKLEY, supra note 7, at 9.

${ }^{53}$ Timothy H. Dixon et al., Space Geodesy: Subsidence and Flooding in New Orleans, NATURE, May 31, 2006, at 587.

54 VAN HEERDEN \& BRYAN, supra note 10, at 73.

${ }_{55}$ Kolbert, supra note 11, at 49.

${ }^{56}$ Id.

57 Mann, supra note 14, at 109. 
structed, 100 miles of marshes served as an effective buffer between residential zones and Gulf storm systems. ${ }^{58}$

In addition to the post-Katrina exodus of more than half the city's residents, ${ }^{59} \mathrm{New}$ Orleans was suffering from a decades-long population decline. ${ }^{60}$ The city's footprint was more appropriate for its pre-1960s population of more than $600,000 .^{61}$ Population decline is relevant to post-disaster recovery efforts because it is difficult, if not fiscally implausible, for a "city shorn of much of its tax base" ${ }^{\text {"62 }}$ to continue to provide effective and efficient public services to residents on a pre-storm population pattern. ${ }^{63}$

The dramatic pace of coastal erosion and land subsidence indicate that the Louisiana coastal region will continue to be susceptible to the devastating effects of even medium-sized hurricanes. This need not deter redevelopment, but it should be kept in mind as policy makers at the city, state, and federal levels respond to Katrina's lasting effects and plan to mitigate the damage sustained in future storm systems. ${ }^{64}$

\section{URA DISPLACEMENT BENEFITS}

The express purpose of the URA is to establish "a uniform policy for the fair and equitable treatment of persons displaced" by programs funded with federal dollars, so that displaced persons do not "suffer disproportionate injuries as a result of programs designed for the benefit of the public as a whole." ${ }^{65}$ The objective of the URA is to ensure "fair, uniform, and equitable treatment" of any person displaced as a direct result of a federally assisted land acquisition. ${ }^{66}$ Furthermore, the URA calls for consideration of "the unique circumstances" of displaced persons so that "persons in essentially similar

\footnotetext{
${ }^{58} I d$.

${ }^{59}$ Varney, supra note 42. Nearly two years after the storm, some estimated the New Orleans population was sixty-two percent of its pre-Katrina level. Adam Nossiter, Largely Alone, Pioneers Reclaim New Orleans, N.Y. Times, July 1, 2007, at 1. However, individual population patterns in individual neighborhoods vary significantly. $I d$.

Baum, supra note 15 , at 46.

${ }^{61} \quad I d$.

${ }^{62} I d$.

63 See Mann, supra note 14, at 96.

${ }^{64}$ Redevelopment efforts may not be faithfully following a redevelopment plan that seeks to mitigate the effect of future storm systems. See Peter Whoriskey, New Orleans Repeats Mistakes as It Rebuilds, WASH. POST, Jan. 4, 2007, at A1.

${ }^{65} 42$ U.S.C. $\$ 4621$ (b) (2000).

${ }^{66}$ Id. $\$ 4621(\mathrm{a})(2)$.
} 
situations are accorded equal treatment" in administering URA benefits. ${ }^{67}$ The URA attempts to ensure that property owners whose homes are acquired by a qualified state agency "receive the replacement value-rather than the market value-of their property." ${ }^{68}$

The URA regulations provide for three tranches of benefits. Benefits enumerated in Subpart B are triggered if property is conveyed involuntarily. ${ }^{69}$ Subpart B benefits include, inter alia, a homeowner's right to an expeditious acquisition of his property, ${ }^{70}$ advance notice of an agency's intent to acquire property, ${ }^{71}$ offers of "just compensation," ${ }^{, 72}$ and certain litigation expenses. ${ }^{73}$ The benefits enumerated in Subparts D and E are triggered if the property owner is considered a "displaced person." ${ }^{\text {"74 }}$ Subpart E provides that an owneroccupant displaced by a qualified state agency ${ }^{75}$ may receive a payment of up to $\$ 22,500$ to acquire replacement housing. ${ }^{76}$ The replacement housing must be "a decent, safe, and sanitary dwelling . . . reasonably accessible to public services and places of employment," functionally equivalent to the acquired property, ${ }^{78}$ adequate in size to accommodate the occupants, ${ }^{79}$ in an area that is "not subject to unreasonable environmental conditions," ${ }^{\prime 0}$ and within the financial

${ }^{67}$ Id. $\S 4621$ (c) (2).

68 Nicole Stelle Garnett, The Neglected Political Economy of Eminent Domain, 105 MicH. L. REV. 101, 121 (2006).

6949 C.F.R. $\$ 24.101(\mathrm{a})$, (b) (2006).

${ }^{70}$ Id. $\$ 24.102(\mathrm{a})$.

${ }^{71} I d . \$ 24.102(\mathrm{~b})$.

${ }^{72}$ Id. $\$ 24.102(\mathrm{~d})-(\mathrm{g})$.

$73 \S 24.107$.

${ }^{74} \S 24.202$ (describing applicability of Subpart C to "displaced persons"); $\$$ 24.301 (describing applicability of Subpart D moving expenses to "displaced persons").

${ }_{75} \S 24.2(\mathrm{a})(1)(\mathrm{iv})$ (2006). "The term State Agency means any department, Agency or instrumentality of a State or of a political subdivision of a State, any department, Agency, or instrumentality, of two or more States or of two or more political subdivisions of a State or States, and any person who has the authority to acquire land by eminent domain." Id.

${ }_{76} 42$ U.S.C. $\$ 4623$ (a) (1); see also 49 C.F.R. $\$ 24.401$.

$77 \S 4623(\mathrm{a})(1)(\mathrm{A})$.

7849 C.F.R. $\$ 24.2$ (a) (6) (ii). Functional equivalency "means that it performs the same function, and provides the same utility. . . . [T] he principle features [of the displacement dwelling] must be present. Generally, functional equivalency is an objective standard, reflecting the range of purposes for which the various physical features of a dwelling may be used." Id.

${ }^{79} \quad I d . \S 24.2(\mathrm{a})(6)$ (iii).

${ }^{80} I d . \S 24.2(\mathrm{a})(6)$ (iv). 
means of the displaced person. ${ }^{81}$ Additionally, under Subpart E, acquiring agencies are permitted to provide financial assistance beyond the statutory maximum on a case-by-case basis if the $\$ 22,500$ amount proves inadequate for the acquisition of comparable replacement housing. ${ }^{82}$ Under Subpart D, displaced homeowners are also entitled to compensation for actual moving expenses, ${ }^{83}$ mortgage and closing costs, ${ }^{84}$ security deposits and credit checks, ${ }^{85}$ living expenses between the taking and acquisition of replacement housing, ${ }^{86}$ and litigation expenses if the government unsuccessfully attempts to acquire a particular piece of property through condemnation proceedings. ${ }^{87}$ While the URA provides significant financial assistance to displaced homeowners ${ }^{88}$ it also preserves a modicum of flexibility for city planners. For example, the comparable replacement dwelling is not required to be in the same neighborhood as the acquired property, ${ }^{89}$ and the replacement dwelling need not contain "every feature of the displacement dwelling." ${ }^{90}$

As noted above, Subparts D and E are triggered if a property owner is considered to be a "displaced person." The statutory and regulatory definitions of "displaced person" have proven to be fluid concepts. As originally envisioned in 1971, a displaced person was

${ }^{81} I d$. $\$ 24.2(\mathrm{a})(6)$ (viii). Replacement housing is "considered to be within the homeowner's financial means if the homeowner will receive the full price differential $\ldots$, all increased mortgage interest costs . . and all incidental expenses . . . " Id. $\S$ 24.2(a) (6) (viii) (A). Similar provisions qualify the affordability of replacement housing for displaced renters. Id. § 24.2(a) (6) (viii) (B).

${ }^{82} 42$ U.S.C. $\$ 4626(\mathrm{a})$; see also 49 C.F.R. $\$ 24.404$ (2006). Evidence suggests super-compensation, i.e., compensation above the statutory maximum, is not unheard of, and may be used both to ensure replacement housing as well as to overcome popular disapproval of takings projects. Garnett, supra note 68, at 122-23.

8342 U.S.C. $\$ 4622$ (a) (1).

${ }^{84}$ Id. Also, businesses are entitled to reestablishment compensation. $\S 4622$ (c). Renters also receive significant protection under the URA, and may receive, among other things, up to sixty times the amount of the difference between their predisplacement and post-displacement rental costs. 24 C.F.R. $\$ 42.350$ (e)(1) (2006); see also Garnett, supra note 68, at 122-23.

24 C.F.R. $\$ 42.350$ (c).

${ }^{86} I d . \S 42.350(\mathrm{~d})$.

8742 U.S.C. $\$ 4654(\mathrm{a})$.

${ }^{88}$ This Comment does not argue that displacement assistance will fully compensate homeowners who lose their home to a state agency. Indeed, full compensation for state acquisition of property from an unwilling seller may be impossible. See generally Rachel Godsil \& David Simunovich, Just Compensation in an Ownership Society, in Private Property, Community Development and Eminent Domain (Robin Paul Malloy ed., forthcoming 2008).

${ }^{89}$ Mejia v. HUD, 518 F. Supp. 935, 938 (N.D. Ill. 1982).

90 Uniform Relocation Assistance and Real Property Acquisition Regulations for Federal and Federally Assisted Programs, 54 Fed. Reg. 8912, 8945 (Mar. 2, 1989). 
defined broadly as "any person who ... moves from real property . . . as a result of the acquisition of such property" by a federally funded program. ${ }^{91}$ In passing the Uniform Relocation Act Amendments of 1987 ("1987 Amendments"), Congress refined the conceptual framework of a displaced person to include a "direct result" element. ${ }^{92}$ Consequently, only those residents displaced from their property as a "direct result ... of the acquisition of such property" by a federally funded program would be considered statutorily protected displaced persons. $^{93}$

The 1987 Amendments also incorporated a provision to further clarify the scope and application of the URA by noting who was not a displaced person. ${ }^{94}$ These negative definitions expressly preclude a resident who unlawfully occupies a home from enjoying URA displacement benefits. ${ }^{95}$ Additionally, individuals who reside on the property for the purpose of obtaining URA benefits, ${ }^{96}$ as well as shortterm renters whose period of tenancy expires before the property is needed by the acquiring agency, are similarly precluded from enjoying URA benefits as they are "persons not displaced."

Following the change in statutory language, the Federal Highway Administration (FHA) revised the URA regulatory framework in 1989. ${ }^{98}$ These regulations expounded upon the displaced person standard and incorporated the direct result element for the acquisition, ${ }^{99}$ rehabilitation, or demolition of real property. ${ }^{100}$ Additionally, a non-exclusive listing of persons not displaced was included. ${ }^{10}$

91 Uniform Relocation Assistance and Real Property Acquisition Policies for Federal and Federally Assisted Programs, 42 U.S.C. § 4601(6) (1976).

${ }^{92}$ Uniform Relocation Assistance and Real Property Acquisition Policies for Federal and Federally Assisted Programs, 42 U.S.C. § 4601(6) (A) (i) (I) (1988).

93 Id.

$94 \S 4601(6)(\mathrm{B})$.

$95 \S 4601(6)(\mathrm{B})(\mathrm{i})$.

${ }^{96} I d$.

$97 \S 4601$ (6) (B) (ii).

98 The Department of Transportation was given the responsibility of promulgating regulations for the implementation of the URA, and the Secretary of Transportation delegated that responsibility to the Federal Highway Administration. Uniform Relocation Assistance and Real Property Acquisition Regulations for Federal and Federally Assisted Programs, 54 Fed. Reg. 8912, 8912 (Mar. 2, 1989). These regulations apply to "acquisition and displacement activities of 18 Federal Agencies." Uniform Relocation Assistance and Real Property Acquisition for Federal and FederallyAssisted Programs, 70 Fed. Reg. 590, 590 (Jan. 4, 2005).

${ }^{99} 49$ C.F.R. $§ 24.2(\mathrm{~g})(1)(\mathrm{i})(1989)$.

$100 \quad I d . \$ 24.2(\mathrm{~g})(1)(\mathrm{ii})$.

101 Id. $\$ 24.2$ (g) (2). 
These regulations were consistent with the statutory changes made by the 1987 Amendments. ${ }^{102}$

The revised regulations preclude mandatory benefits under Subpart B if an "owner-occupant . . . voluntarily conveys his or her property, as described in $\S 24.101(\mathrm{a})(1)$ and (2)."103 Section 24.101(a) (1) describes a voluntary conveyance as one in which "no specific site or property needs to be acquired," 104 the property in question "is not part of an intended, planned, or designated project area," 105 and it will not be acquired if the owner-occupant and the acquiring agency fail to reach a mutually satisfactory agreement. ${ }^{106}$ The acquiring agency must also relate to the owner "what it believes to be the fair market value of the property." ${ }^{107}$ For a transaction to be considered "voluntary," each of the four criteria must be satisfied. ${ }^{108}$ In addition, section 24.101(a)(2) provides that displacement benefits are not to be extended if the acquiring agency is not vested with the authority to exercise eminent domain. ${ }^{109}$ This facially unequivocal language could be interpreted to preclude a cause of action for displacement benefits for Katrina-displacees because the Road Home is not vested with the power of eminent domain.

Before proceeding, it is important to reinforce the fact that the voluntariness of a certain transaction governs Subpart B benefits only. ${ }^{110}$ Benefits under Subparts D and E are triggered only if the homeowner is a "displaced person" under the URA. ${ }^{111}$ There is, without doubt, a large degree of overlap between the triggering events; but the standards are nevertheless different. Katrina displacees should be considered "displaced persons" if they moved as a "direct

102 Compare $§ 24.2(\mathrm{~g})(2)$ with Uniform Relocation Assistance and Real Property Acquisition Policies for Federal and Federally Assisted Programs, 42 U.S.C. $\S$ 4601(6) (A) (1988).

${ }^{103} \S 24.2(\mathrm{~g})(2)$ (viii).

$104 \quad I d . \S 24.101(\mathrm{a})(1)(\mathrm{i})$.

105 Id. $\$ 24.101(\mathrm{a})(1)(\mathrm{ii})$.

106 Id. $\$ 24.101$ (a) (1) (iii).

107 Id. $\$ 24.101(\mathrm{a})(1)(\mathrm{iv})$.

108 Id. $\$ 24.101(\mathrm{a})(1)$.

10949 C.F.R. $\$ 24.101$ (a) (2) (1989). Subpart B benefits will not be extended under this provision so long as the acquiring agency "clearly advise[s] the owner that it is unable to acquire the property" through eminent domain proceedings should the parties fail to come to an agreement. Id. \$24.101(a)(2)(i). Additionally, the owner must be informed as to what the acquiring agency believes is the "fair market value of the property.” Id. §24.101(a) (2) (ii).

110 See supra note 74 and accompanying text.

11149 C.F.R. $§ 24.301$ (a) (2006); Id. § 24.401(a). 
result of . . . the acquisition" of their homes by the Road Home. ${ }^{112}$ As explained in Part III, homeowners who relocated because of Katrina will be protected under a theory of constructive occupancy. ${ }^{113}$ Their displacement was prolonged by the Road Home, ${ }^{114}$ and once their property is formally acquired by the program, the displaced homeowners will be eligible for benefits under Subparts D and E.

Three arguments can be made to rebut the apparent prerequisite for eminent domain power to trigger Subpart B benefits. First, section 24.101, while facially unequivocal, is in reality more nuanced and reflects the underlying regulatory and legislative framework within which displacement arises. ${ }^{115}$ Second, section 24.101 is without the weight of law because it impermissibly narrows the scope and application of the URA. Third, the buyout-only provision amounts to an involuntary conveyance of property under the URA, thereby satisfying even the narrowest interpretation of the scope of section 24.101 under a theory of "functional takings."

\section{THEORIES OF RECOVERY UNDER THE URA}

\section{A. The Regulations are More Nuanced Than Their Facially Unequivocal Language}

That the Road Home is not vested with the power of eminent domain does not preclude Katrina-displacees from successfully pursuing Subpart B benefits, despite the ostensibly unambiguous language of section 24.101. As noted above, section 24.101(a)(2) expressly precludes URA benefits if the acquiring agency does not have the power of eminent domain. ${ }^{116}$ However, in explicating the scope of section 24.101, the FHA noted that "[e]minent domain authority is not a determining factor by itself." ${ }^{117}$ Moreover, the 1987 Amendments were described as expanding the scope of the URA "to include any private entity that has the power of eminent domain under Fed-

11242 U.S.C. $\$ 4601(6)$ (A) (i) (I).

113 See infra Part III.C.1.

114 See supra notes 39-41 and accompanying text.

115 This inquiry, of course, assumes that property acquired by the Road Home would fulfill each of the four tests contemplated by $\S 24.101$ (a) (1) (i-iv). However, it is likely that Road Home acquisitions would fail the second test, as acquired property would likely considered part of an "intended, planned, or designated project area." $\S 24.101(\mathrm{a})(1)$ (ii).

${ }^{116} I d . \$ 24.101(\mathrm{~b})(2)$.

117 Uniform Relocation Assistance and Real Property Acquisition Regulations for Federal and Federally Assisted Programs, 54 Fed. Reg. 8912, 8918 (Mar. 2, 1989). 
eral or state law." ${ }^{118}$ The use of federal dollars to finance property acquisition-not the eminent domain power-"is the basic determinant for [URA] applicability." ${ }^{119}$ Moreover, section 24.101 is motivated by an administrative intent to differentiate between voluntary, arm's-length transactions between government-buyers and homeowner-sellers, ${ }^{120}$ and federally funded involuntary conveyances. ${ }^{121}$ Moreover, the URA's preference for substance over form(and the emphasis on involuntariness, rather than the presence or absence of eminent domain authority) was recognized by the FHA itself when it noted that " $[\mathrm{t}]$ he essence of a voluntary transaction is the conditions surrounding the transaction, not the type of transaction itself." ${ }^{122}$

Considering the statutory and administrative intent, it is apparent that the regulations are more nuanced than they initially appear. Understood in its proper context, the reference to eminent domain power is nothing more than a useful short-hand approach-but ultimately not a dispositive element-in assessing whether an acquiring agency must provide Subpart B benefits.

The FHA revised the URA regulations in 2005, and it is only with the proper understanding of the 1987 Amendments and their corresponding regulations that the more recent regulations can be placed in appropriate context and accorded the correct interpretation. Notably, the 2005 revisions amended the regulatory framework in the absence of any change to the relevant statutory language of the URA. ${ }^{123}$

The definition of displaced person, redesignated in 2005 as section 24.2(a) (9), remained substantively equivalent to its 1989 counterpart. $^{124}$ The definition of persons not displaced is also left largely,

118 Uniform Relocation Act Amendments of 1987, 52 Fed. Reg. 18768, 18769 (May 19, 1987).

${ }^{119}$ Uniform Relocation Assistance and Real Property Acquisition Regulations for Federal and Federally Assisted Programs, 54 Fed. Reg. at 8918. The Federal Register goes on to explain that "any acquisition made under the threat of eminent domain is clearly subject to [the URA]." Id.

120 The government-buyer includes qualified state agencies, which encompasses agencies created by the state as well as individuals vested with the power of eminent domain. 49 C.F.R. § 24.3(a) (1) (iv) (2006).

121 Uniform Relocation Assistance and Real Property Acquisition for Federal and Federally-Assisted Programs, 70 Fed. Reg. 590, 596 (Jan. 4, 2005).

${ }^{122}$ Uniform Relocation Assistance and Real Property Acquisition Regulation for Federal and Federally Assisted Programs, 52 Fed. Reg. 47994, 48011 (Dec. 17, 1987).

${ }^{123}$ Compare 42 U.S.C.A. $\S \S 4601-4655$ (2003 \& Supp. 2007) with 42 U.S.C. $\$ \S$ 4601-4655 (1988).

124 Compare 49 C.F.R. $\$ 24.2(\mathrm{a})$ (9) (i) (2005) with 49 C.F.R. $\$ 24.2$ (g) (1) (i) (1989). 
but not entirely, unchanged. ${ }^{125}$ Most relevant for purposes of this Comment, the 2005 regulatory definition of displaced person omitted reference to "voluntary" conveyances as defined in section 24.101. ${ }^{126}$ In the 1989 regulations, the definition of "persons not displaced" included an "owner-occupant who voluntarily convey[s] his or her property" to the acquiring agency as described in section 24.101. ${ }^{127}$ However, the 2005 revisions omit the "voluntary" language-providing instead that displacement benefits should not be extended to "[a]n owner-occupant who conveys his or her property" to the acquiring agency in a transaction described in section $24.101 .{ }^{128}$ The purpose of omitting the "voluntary" language in the 2005 revisions is not explained in the Federal Register. ${ }^{129}$ The omission appears to reflect a change in section 24.101, which in its 2005 manifestation does not distinguish between voluntary and involuntary direct acquisitions by federal programs ${ }^{130}$ (as opposed to state programs funded by federal dollars). URA applicability to federally funded state programs, as described in section 24.101(b), remains exactly the same as the corresponding 1989 regulations. ${ }^{131}$ As a result, acquisitions made by the Road Home-a federally funded state programwould still be evaluated by the voluntariness principle. ${ }^{132}$

Despite the facially unequivocal language of the regulation, eminent domain power is only indicative, and not dispositive, of a URA triggering event. The statutory language and the regulatory framework pertaining to federally financed state acquisitions remained virtually unchanged in the 2005 regulatory revisions. As a result, the goal of providing equitable treatment to displaced homeowners who involuntarily convey property to an acquiring agency remains the linchpin Subpart B benefits. Consequently, Katrina-

125 One substantial change is the preclusion of URA benefits for "[a] person who is not lawfully present in the United States.” 49 C.F.R. § 24.2 (a) (9) (ii) (L) (2005).

${ }^{126} I d . \S 24.2(\mathrm{a})(9)(\mathrm{ii})(\mathrm{H})$.

12749 C.F.R. $\$ 24.2$ (g) (2) (viii) (1989).

12849 C.F.R. $\$ 24.2(\mathrm{a})(9)(\mathrm{ii})(\mathrm{H})$ (2005)

129 Uniform Relocation Assistance and Real Property Acquisition for Federal and Federally-Assisted Programs, 70 Fed. Reg. 590, 590-606 (Jan. 4, 2005).

${ }^{130} \S 24.101(\mathrm{a})(1)$. Even this facially unequivocal language is tempered by Appendix A, which states that, despite the language of section 24.101, direct federal acquisitions that are voluntary in nature will not trigger the URA if the acquiring agency does not have "recourse to the power of eminent domain." Uniform Relocation Assistance and Real Property Acquisition for Federal and Federally-Assisted Programs, 70 Fed. Reg. at 595-96. Thus, the voluntariness principle applies to both the direct federal acquisitions and acquisitions by federally funded programs.

131 Compare $\$ 24.101$ (b) (2005) with $\$ 24.101$ (a) (1) (1989).

132 See 49 C.F.R. $\$ 24.101$ (b) (2005). 
displacees are not precluded from receiving URA displacement benefits simply because the Road Home is not vested with the power of eminent domain.

\section{B. A Narrowly Construed Eminent Domain Provision Manifestly Contradicts the Unambiguous Intent of the URA}

If the reference to eminent domain is interpreted narrowlythat is, if it is interpreted to require the presence of the eminent domain power to trigger Subpart B benefits-it would impermissibly narrow the scope and application of the URA and would consequently be without the weight of law. Assuming a reviewing court determines that Congress did not clearly express its intent to apply the voluntariness test, the FHA's regulations would be examined for reasonableness. ${ }^{133}$

Congress expressly authorized the FHA to promulgate regulations to administer the URA. ${ }^{134}$ These regulations are entitled to "controlling weight unless they are arbitrary, capricious, or manifestly contrary" to the statute. ${ }^{135}$ Regulations do not carry the force of law if they are irreconcilable with the "clear meaning of the statute, as revealed by its language, purpose, and history." ${ }^{36}$ While "considerable weight should be accorded to an executive department's construction of a statutory scheme it is entrusted to administer," ${ }^{137}$ deference to an agency's policy expertise does not merit granting carte blanche authority to promulgate regulations that contradict congressional intent.

Under Cheuron, courts first ask whether there is clear congressional intent respecting the issue at hand, and if not, whether the agency's interpretation of the underlying statute is reasonable. ${ }^{138}$ As discussed below, the statutory scheme and legislative history of the URA clearly and unequivocally expresses congressional intent to avoid any mechanistic, dispositive eminent domain requirement.

\footnotetext{
133 Chevron, U.S.A., Inc. v. Natural Res. Def. Council, Inc., 467 U.S. 837, 844 (1984).

13442 U.S.C. $\$ 4604$ (b) (1) (2000).

135 Chevron, 467 U.S. at 844; see also 5 U.S.C. $\$ 706$ (2)(A) (requiring reversal of agency action determined by a court to be "arbitrary, capricious, an abuse of discretion, or otherwise not in accordance with law").

${ }^{136}$ Se. Cmty. Coll. v. Davis, 442 U.S. 397, 411 (1979); see also Finkler v. Elsinore Shore Assocs., 781 F. Supp. 1060, 1064 (D.N.J. 1992).

137 Chevron, 467 U.S. at 845.

138 Chevron, 467 U.S. at 843
} 
The 1987 Amendments significantly expounded upon the express declaration of policy accompanying the URA. ${ }^{139}$ As amended, the statute calls for "fair, uniform, and equitable treatment of all affected persons," ${ }^{140}$ and reaffirms a specific commitment to improving the "housing conditions of economically disadvantaged persons." In explaining the language behind the amended language, Senator David Durenberger, a co-sponsor of the 1987 Amendments, explained that the declaration of policy establishes that a URA triggering event can arise outside of traditional property acquisitions. ${ }^{142}$ Moreover, it was intended that "uniformity should be subordinate to the need for flexibility in administering the URA." ${ }^{143}$ In addition to promoting principles of administrative flexibility, the 1987 Amendments were designed to "broaden the applicability of the act to include persons not . . . eligible for assistance" under the 1971 provisions. ${ }^{144}$ The Federal Register is replete with statements by the FHA recognizing the URA's mandate for flexibility over uniformity, and fact-intensive inquiries into voluntariness rather than a cursory eminent domain litmus test. ${ }^{145}$

The enumeration of federal and state agencies required to comply with the URA ("covered entities") was also amended in 1987. Specifically, the 1987 Amendments amended the definition of covered entities to include those vested with the power of eminent domain. ${ }^{146}$ The fact that the eminent domain provision was added to the list of covered entities is significant. Proposed versions of the amended language-which were never passed by Congress-called for replacing the description of covered entities with a simple, but markedly less flexible, definition of a covered entity to include only those entities

139 Compare 42 U.S.C. $\$ 4621$ (2000) with 42 U.S.C. $\$ 4621$ (1976).

14042 U.S.C. $\$ 4621$ (a) (2) (2000).

${ }^{141}$ Id. $\$ 4621$ (c) (3). See also 133 CONG. REC. S1560 (daily ed. Feb. 3, 1987) (statement of Sen. Durenberger) ("Of particular concern to the committee are those economically disadvantaged who are least able to afford suitable replacement housing and who are involuntarily displaced.").

${ }^{142}$ See Uniform Relocation Act Amendments of 1985, S. 249, 99th Cong., as reprinted in 131 CONG. REC. S495 (daily ed. Jan. 22, 1985).

${ }^{143}$ Id.; see also S. REP. No. 98-71 (1983), as reprinted in 133 CONG. REC. S1560 (daily ed. Feb. 3, 1987) ("The committee's revisions are largely intended to establish the conditions under which regulatory flexibility is preferable to uniformity.").

144 S. ReP. No. 98-71 (1983), as reprinted in 133 CONG. REC. S1560 (daily ed. Feb. 3, 1987)

${ }^{145}$ See supra Part III.A.

14642 U.S.C. $\$ 4601(1)$, (3). 
vested with the power of eminent domain. ${ }^{147}$ In adopting the more flexible language, Congress rejected the notion that URA benefits could be triggered only by an entity vested with the power of eminent domain. Moreover, in a report on the proposed amendments, the Senate Committee on Governmental Affairs explained that "acquisition of property under eminent domain, or the threat thereof, is not the only cause of the permanent and involuntary displacement of a person." ${ }^{148}$

If the eminent domain provision in the 1989 regulations is interpreted narrowly-as dispositive rather than merely probativethen the statutory framework and legislative history outlined above demonstrates that the narrowed interpretation manifestly contradicts clear and unambiguous congressional intent and should not be accorded the weight of law. ${ }^{149}$ Despite unambiguous statutory language, ${ }^{150}$ and contrary to legislative intent, ${ }^{151}$ the regulatory eminent domain provision improperly exalts uniformity over Congress's express desire for administrative flexibility. As described above, the 1987 Amendments were intended to broaden the class of people protected by the URA, and it was expressly noted that displacement benefits could be triggered absent the exercise of the eminent domain power. ${ }^{152}$ If interpreted narrowly, however, the regulations promulgated in 1989 would significantly curtail URA benefits so as to apply only to the exceptional class of displaced residents who are forced to relocate because of traditional eminent domain takings. Consequently, the putative regulatory requirement of eminent domain authority to trigger Subpart B benefits should not be accorded the weight of law since the regulations manifestly contradict the statutory framework and legislative intent informing the URA.

${ }^{147}$ Uniform Relocation Act Amendments of 1985, S. 249, 99th Cong., as reprinted in 131 Cong. ReC. S10669 (daily ed. Aug. 1, 1985).

${ }^{148}$ S. ReP. No. 98-71 (1983), as reprinted in 133 CONG. REC. S1561 (daily ed. Feb. 3, 1987)

${ }^{149}$ Chevron, U.S.A., Inc. v. Natural Res. Def. Council, Inc., 467 U.S. 837, 844 (1984).

150 See, e.g., 42 U.S.C. $\$ 4621$ (a) (1) (recognizing that a person may be displaced by a number of activities, only one of which is acquisition).

151 See supra notes 117-22, 142-48 and accompanying text.

152 See supra notes $117,119,122,148$, and accompanying text. 


\section{Assuming a Narrow Construction of the Eminent Domain Provision, the Buyout-Only Provision is a URA Triggering Event Under a Theory of Functional Takings}

Under a narrow interpretation of the eminent domain provision, and assuming the regulations are accorded the weight of law, the Road Home buyout-only provision nevertheless triggers URA displacement benefits. The buyout-only provision amounts to a "functional taking" of property under the URA. There are two hurdles that a viable cause of action under the URA must clear on its way to judicial recognition under this approach: the policy of constructive occupancy, and the theory of "functional takings." 153

\section{Constructive Occupancy}

The URA mandates that a displaced person occupy the acquired residence for 180 days prior to acquisition to be eligible for relocation benefits. ${ }^{154}$ This threshold requirement would preclude URA benefits where an individual lives in one home, and a qualified

${ }^{153}$ It should be noted as an initial matter that the theory of "functional takings" as applied in this Comment does not assume the same scope as it would in the eminent domain context. The standard for a URA-triggering event is not an eminent domain taking but is instead reviewed for a more flexible, equitable standard of voluntariness. It is in this context that "functional taking" as used in this Comment should be interpreted. The term should not be confused with the scholarly use of the term as a reference to certain regulatory takings. See, e.g., Daniel A. Farber, Public Choice and Just Compensation, 9 Const. Comment. 279, 304 (1992) (describing "regulations that are functionally equivalent to government acquisitions" as takings); Christopher L. Harris \& Daniel J. Lowenberg, Recent Developments: Kelo v. City of New London, Tulare Lake Basin Water Storage District v. United States, and Washoe County v. United States: A Fifth Amendment Primer, 36 ST. MARY's L.J. 669, 687 (2005) (referring to "the functional equivalent to a physical taking" in describing the Supreme Court's decision in Lucas v. S.C. Coastal Council, 505 U.S. 1003 (1992)); Barbara White, Coase and the Courts: Economics for the Common Man, 72 IowA L. REv. 577 (1987) (describing the application of the Coase Theorem as resulting in a "functional equivalent of taking of private property without compensation" in certain instances).

Furthermore, functional takings for purposes of the URA is substantively different than a constructive taking in the eminent domain context, although similar arguments can be made for both doctrines. Constructive takings arise when a condemning authority engages in a course of unconstitutional conduct intended to force homeowners to sell property to the government at depressed values. See, e.g., Amen v. City of Dearborn, 718 F.2d 789, 794-96 (6th Cir. 1983) (finding that city government engaged in conduct amounting to a constructive taking of property when the city, inter alia, manipulated permits to limit homeowner renovations, indicated compensation would be reduced the longer homeowners waited to sell their property, and repeatedly informed the residents that their property was subject to condemnation). A functional taking for purposes of the URA need not meet the more rigid requirements of eminent domain takings; rather, it must only be evident that the conveyance was not voluntary. See supra Part II.

15442 U.S.C. $§ 4623(\mathrm{a})(1)$. 
agency acquires a property upon which the individual was constructing a second home with the intention that it would ultimately be his primary residence. ${ }^{155}$ Alternatively, URA benefits would not be triggered if an individual's completed second home is involuntarily conveyed to an acquiring agency if the acquired home is not intended to be a primary residence. ${ }^{156}$

The plain language of the 180-day requirement might appear to preclude the recovery of URA benefits by Katrina displacees. The argument would likely be made that (1) Road Home displacement benefits are unwarranted in cases where property owners did not occupy their homes for the required 180-day period prior to acquisition, and (2) even if the 180-day requirement is satisfied or overlooked, it was a natural disaster, not a federally financed acquisition, that forced residents out of their homes. Neither contention holds water.

State and federal acquiring agencies argued the validity of the constructive occupancy policy before a number of courts, ${ }^{157}$ despite the fact that it is not codified in any provision of the URA or its regulations. ${ }^{158}$ The doctrine was first recognized in Seeherman v. Lynn, a case in which residents of Wilkes-Barre, Pennsylvania were displaced by Hurricane Agnes and whose properties were subsequently acquired by a federally funded redevelopment authority. ${ }^{159}$ In Seeherman, the court found that the theory of constructive occupancy "provided that all owners of property . . . who occupied their homes on the day prior to [a natural disaster] would be eligible to receive relocation assistance."

The origin of the constructive occupancy policy is unclear but has not been refuted since Seeherman was decided in 1975. The Seeherman court noted that the policy may be attributable to the Disaster Relief Act of 1970, mandating that relocation benefits may not be

155 Seeherman v. Lynn, 404 F. Supp. 1318, 1319-20 (M.D. Pa. 1975).

156 See Ledesma v. Urban Renewal Agency, 432 F. Supp. 564, 565-67 (S.D. Tex. 1977) (by implication). The court in Ledesma also found it relevant that the homeowners in question, who were deemed to have a case strong enough to survive the defendant's motion for summary judgment, were forced to live in a second home because of economic hardship. Id. at 565. Consequently, the court found that under the policy of constructive occupancy, the homeowners were not precluded from receiving displacement benefits under the URA even though they were not residing in the acquired home at the time of acquisition. Id. at 567.

157 See generally Nagi v. United States, 751 F.2d 826, 830 (6th Cir. 1985); Ledesma, 432 F. Supp. at 567; Seeherman, 404 F. Supp. at 1321-22.

${ }_{158}$ Seeherman, 404 F. Supp. at 1320 n.1.

${ }^{159}$ Id. at 1319-20.

160 Id. at 1320 . 
withheld if an otherwise eligible homeowner is denied benefits because she was prevented from reestablishing occupancy due to a presidentially declared disaster. ${ }^{161}$ The court offered this perspective despite the fact that the provision in question applied only to the URA's predecessor, not to the URA itself. ${ }^{162}$ Two years after Seeherman, a district court in Ledesma $v$. Urban Renewal Agency offered a more persuasive analysis of the origin of the constructive occupancy policy. ${ }^{163}$ The court presumed that the policy originated with the URA's requirement that residents displaced by a federally funded program receive fair and equitable treatment. ${ }^{164}$ The court relied on information in the U.S. Department of Housing and Urban Development's (HUD) Relocation Handbook, which articulated the constructive occupancy policy as a means of mitigating what might otherwise be inequitable results from the strict application of the URA's statutory and regulatory provisions. ${ }^{165}$

\section{Actual Displacement Through Functional Takings}

The second and admittedly more complicated hurdle to judicial recognition of a URA-based cause of action is the theory of "functional takings." As explained above, Road Home rehabilitation funding is not available to residents residing "in an area where a high proportion of homeowners are choosing not to invest" in their homes. ${ }^{166}$ City officials publicly claimed that no communities would be targeted for planned elimination; however, the choice may yet be forced on them as funding shortages continue to plague redevelopment efforts. ${ }^{167}$ Moreover, the provision's pernicious effects were felt in the months immediately following the storm, and will have the same effect on economically disadvantaged homeowners regardless of whether the buyout-only restriction is actually implemented. ${ }^{168}$

The "functional takings" theory is based on the principle that "[a]cceptance of decision-making power requires acceptance of the

${ }^{161} I d$. at 1322 n.5 (citing Disaster Relief Act of 1970, 42 U.S.C. $§ 4484$ (1970)).

$162 I d$.

163 Ledesma v. Urban Renewal Agency, 432 F. Supp. 564, 567 (S.D. Tex. 1977).

164 Id.

165 Id. at 567 n.1.

166 LRA, ACTION Plan AMEndment, supra note 39, at 6-7.

167 Nossiter, supra note 59, at 1 (describing funding shortages in the Road Home as well as a complete absence of funding for the city's own billion-dollar redevelopment plan).

168 See supra note 41. 
responsibility for the predictable effects of that power." ${ }^{169}$ The displacement of New Orleans residents is both a planned and predictable effect of the Road Home buyout-only provision. ${ }^{170}$ The program provides homeowners with a means of selling property to the state so the property owner can move out of a neighborhood or the state entirely. Additionally, the ambiguities surrounding the administration of the Road Home serve to reinforce displacement. ${ }^{171}$ A Rand Corporation ${ }^{172}$ study, conducted in response to Gulf Coast redevelopment, explained that

[i] ndividual and collective decisions about how to proceed with reconstruction in the affected areas of the Gulf Coast are interconnected in complex ways, sometimes referred to in shorthand as the "chicken and egg" problem. Uncertainty about the future level of protection will temper or tip investments and the rebuild/relocate decisions that ultimately shape the scope of reconstruction. ${ }^{173}$

Thus, the uncertainty about the potential benefits extended to returning homeowners in the months following Katrina created a disincentive to return and invest financial resources and sweat equity in rebuilding storm-damaged homes. ${ }^{174}$ In turn, this disincentive compounded the uncertainty besetting residents and policy makers in determining which communities could ultimately thrive in post-Katrina New Orleans. ${ }^{175}$ Indeed, no greater uncertainty could exist than the combination of the Road Home's cryptic admission that it had not determined how to identify neighborhoods where too few homeown-

${ }^{169}$ Peter W. Salsich, Jr., Displacement and Urban Reinvestment: A Mount Laurel Perspective, 53 U. Cin. L. REv. 333, 362 (1984).

${ }^{170} I d$.

171 Nossiter, supra note 59, at 1 (noting that as of July 1, 2007-nearly two years after Katrina made landfall-only twenty percent of eligible homeowners who applied for Road Home funding received checks).

172 Rand Corporation, http://www.rand.org (last visited Oct. 10, 2007). "The Rand Corporation is a nonprofit institution that helps improve policy and decisionmaking through research and analysis." Id. at http://www.rand.org/about/.

173 KAHAN ET AL., supra note 23, at 39.

174 Nossiter, supra note 59, at 1.

175 Anecdotal evidence also suggests that homeowners who have returned must navigate through a cripplingly slow bureaucracy in order to receive the promised recovery assistance. James Varney, What a Drag, Times-PicaYune (New Orleans), Oct. 27, 2006, at 1. Displaced residents who visited the Orleans Parish Mortgage Conveyance Office for necessary paperwork found that they needed to wait two days to speak with a representative. Id. The problem facing the residents, and the conveyance office, is largely one of supply and demand. The supply of experienced employees has dwindled, yet the demand for the services has grown exponentially. Id. 
ers were choosing to reinvest and its cripplingly slow delivery of federal funding.

Areas in which "too few homeowners are choosing" to reinvest will likely be the areas where residents have the least disposable income to devote to post-storm rehabilitation and were least able to afford homeowners insurance prior to the flooding. ${ }^{176}$ In a 1979 report, HUD recognized that the effects of displacement are particularly disruptive to families with lower incomes. ${ }^{177}$ Thus, it is necessary to consider the socioeconomic status of the displaced residents. ${ }^{178}$

Based on data from the U.S. Census Bureau, the residents of the Lower Ninth Ward can undoubtedly be characterized as a "socially vulnerable population." ${ }^{\prime 79}$ Nearly ninety percent of the population is African American and more than one-third of the residents do not have a high school degree. ${ }^{180}$ The median household income in 1999 was less than half of the national average, ${ }^{181}$ median family income was sixty percent lower than the national average, ${ }^{182}$ and nearly four

176 Salsich, Jr., supra note 169 , at 335 n.8.

Displacement disproportionately affects socially vulnerable populations: minorities, low-income households, female-headed households and renters. Each of these groups has particular attributes that contribute substantially to the inability of displaced persons to find housing under the "filtering" concept. First, minorities often are barred from access to many submarkets through discrimination. Low income households are limited to certain markets purely by cost. Femaleheaded households are almost low-income by definition; $33 \%$ of them fall below the poverty line. A report of the United States Commission on Civil Rights states that in 1981 the poverty rate for persons in black, female-headed households was $68 \%$.

Id. (internal citations omitted). Indeed, nearly two years after the storm, New Orleans's poorest neighborhoods remain largely abandoned. Nossiter, supra note 59, at 1 .

177 U.S. Dep't of Hous. \& Urban Dev., Displacement Report 24 (1979).

${ }^{178}$ Salsich, Jr., supra note 169, at 335 n.9 ("The impact of any forced move is correlative to income levels.")

${ }^{179}$ Id. at 335 n.8.

180 U.S. Census Bureau, Zip Code Tabulation Area 70117, http://factfinder. census.gov (enter zip code "70112" under "Get a fact sheet for your community"). The percentage of Ninth Ward residents with high school degrees is $61.7 \%$, while the national average is more than eighty percent. Id.

${ }^{181} I d$. The median income of Ninth Ward residents is $\$ 19,567$ and the national average is $\$ 41,994$. Id. This is also one third lower than the median income of Louisiana residents, which was $\$ 32,566$ in 2000. U.S. Census Bureau, Louisiana Census 2000 Demographic Profile Highlights, http://factfinder.census.gov (select "Louisiana" under "Get a fact sheet for your community"; click the "2000" tab).

${ }^{182}$ U.S. Census Bureau, supra note 180. The median family income in the Ninth Ward is $\$ 21,721$, compared to the national median family income of $\$ 50,046$. Id. 
times as many families lived in poverty than in the nation as a whole. ${ }^{183}$ However, despite the dismal economic statistics, a high percentage of Ninth Ward residents are homeowners compared to the national average. ${ }^{184}$ Acknowledging that residents of the Ninth Ward are generally not as wealthy as their state and national counterparts is not meant to suggest that any federal program that creates incentives for a state buyout of property triggers the URA if the sellers are of limited financial means. Rather, this is meant to reinforce the express purpose of the URA to consider the unique circumstances of those affected by federally financed redevelopment efforts. ${ }^{185}$

The theory of "functional takings" is consistent with the purpose of the URA. It recognizes the reality of the Road Home buyout-only provision-specifically, that a state buyout is the only rational option for displaced homeowners of limited financial means. This category of property transfers to the Road Home cannot be characterized as a voluntary conveyance falling outside the protection of the URA. ${ }^{186}$

As explained above, homeowners will have the opportunity to self-finance the renovation of their homes. ${ }^{187}$ Considering the low median income, high percentage of homeowners who own their homes, and the complete and utter devastation of the homes in the Ninth Ward, this "alternative" will likely be entirely unrealistic for a substantial portion of Ninth Ward residents. ${ }^{188}$

Alternatively, homeowners will have the option to sell their homes on the open market. ${ }^{189}$ This option clearly assumes that there is something left to sell. However, the wall of water that rushed into the Ninth Ward completely destroyed homes in the immediate vicinity of the levee breach, removed others from their foundations, and

${ }^{183}$ Id. Of the families in the Ninth Ward, $34.0 \%$ lived below the poverty line in 2000, compared with only $9.2 \%$ for the nation as a whole. Id.

${ }^{184}$ The Greater New Orleans Community Data Center, Lower Ninth Ward Neighborhood: Housing \& Housing Costs, http://www.gnocdc.org/orleans/8/22/ housing.html (last visited Oct. 10, 2007). The Greater New Orleans Community Data Center reports that as of the year 2000 (most recent data available), fifty-nine percent of Lower Ninth Ward residents owned and occupied their homes, compared to $66.2 \%$ for the nation as a whole. Id.

18542 U.S.C. $\$ 4621$ (c) (2) (2000).

186 See supra notes 103-09 and accompanying text.

187 LRA, RoAd Home Overview, supra note 32, at 8.

188 The Census statistics reveal low household wealth, indicating the difficulty Ninth Ward residents would likely have in financing renovations by using their savings. Moreover, the increase in monthly recurring costs will likely preclude poorer homeowners from financing the renovation over a long period of time.

189 LRA, RoAd Home OVERVIEW, supra note 32, at 4. 
submerged everything else in fourteen feet of water. ${ }^{190}$ As a result of this complete devastation, this subset of homeowners will likely receive nothing more than the value of the land on which their homes were formerly located if they were to sell on the open market. As with the self-financing option, the open-market sale "alternative" hardly presents homeowners with even the semblance of choice. This distressing reality leads to one ineluctable outcome for affected homeowners: sell to the state at a pre-storm fair market value. Consequently, certain Road Home acquisitions should properly be considered "functional takings" for purposes of the URA, thereby moving the property conveyance away from the realm of voluntariness and triggering URA displacement benefits.

\section{CONCLUSION}

Some may argue that compelling URA benefits punishes the Road Home for its generosity as the program essentially gives qualified residents free retroactive flood insurance. This argument carries at least superficial appeal. However, a court must examine the practical effect, logical coherence, and statutory framework governing post-disaster redevelopment. ${ }^{191}$ First, if Road Home administrators ultimately categorize certain neighborhoods as buyout-only, it will be an express attempt to further the broader public weal to the detriment of those homeowners who would otherwise benefit from the redevelopment program. Second, widespread displacement was aggravated by the ambiguities created by Road Home administrators. Specifically, program administrators (1) failed to determine which neighborhoods, if any, would be affected by the buyout-only restriction, (2) failed to articulate guidelines quickly and clearly so residents could choose to rebuild or relocate, and (3) failed to promptly distribute grant monies to qualified homeowners.

There is a natural predilection to rebuild what once was, yet difficult and politically unpalatable choices must be made if the realities facing the Gulf Coast are to be honestly and compassionately confronted. ${ }^{192}$ The people of New Orleans have suffered tremendously since the summer of 2005, and while the devastation wrought by Hurricane Katrina, exacerbated by governmental failures at every level, caused billions of dollars in damage and took the lives of 1500 indi-

190 VAN HEERDEN \& BRYAN, supra note 10, at 84

191 Cass Sunstein, Interpreting Statutes in the Regulatory State, 103 HARV. L. REV. 405, 424-34 (1989).

192 KAHAN ET AL., supra note 23, at xiii. 
viduals, reason for optimism remains. Residents, community groups, and policy makers have a uniquely powerful and dynamic chargerebuild a great city. In so doing, three principles must guide the effort: effectiveness, efficiency, and equity.

Effective redevelopment hinges on whether city, state, and federal officials forthrightly confront the confluence of disappearing wetlands, land subsidence, and an inadequate levee system. Efficient redevelopment relies on vesting city planners and policy makers with both the discretion and the leadership to concentrate redevelopment in order to facilitate the provision of critical infrastructure and city services. A smaller city, at least in the short term, may be a necessary evil brought about by the reality of permanent and semi-permanent displacement, which in turn places severe constraints on city services.

Equally important is that redevelopment efforts be guided by principles of equity and comply with the uniform federal displacement policy. After Katrina, a smaller New Orleans serves the public welfare, a reality acknowledged in the Road Home's buyout-only provision, and the affected residents should not be forced to "suffer disproportionate injuries as a result" of the planned redevelopment. ${ }^{193}$ Moreover, the "choices" the Road Home provides certain homeowners ultimately leads to a single inescapable outcome, thereby removing the critical element of voluntariness from buyout-only acquisitions. Implementing the status-preserving principles embodied in the URA can potentially transform the Road Home from the single largest housing recovery program to one that is also effective, efficient, and equitable.

In the end, however, the scope of this Comment is broader than either Hurricane Katrina or the Road Home. Both are offered and analyzed here as templates of future disasters and corresponding recovery efforts. It is crucial that government officials, community groups, practitioners, and the general public understand the scope and application of the URA. The element of voluntariness embedded within the URA's statutory and regulatory framework can redefine future post-disaster redevelopment efforts, and provide government officials the flexibility to offer unique and resource-efficient recovery plans while simultaneously protecting the homeowner status of displaced residents.

\footnotetext{
19342 U.S.C. $§ 4621$ (b) (2000).
} 